International Journal of Lakes and Rivers.

ISSN 0973-4570 Volume 14, Number 2 (2021), pp. 211-222

(C) Research India Publications

https://dx.doi.org/10.37622/IJLR/14.2.2021.211-222

\title{
Hydrochemical Assessment of Groundwater in the Spit-Bar System of Chilika Lagoon in Krushnaprasad Block, Odisha, India
}

\author{
Satyabrat Sahoo, Jagadish Kumar Tripathy*, S. R. Panda and D. Sahoo \\ Department of Earth Sciences, Sambalpur University \\ *Corresponding Author
}

\begin{abstract}
Groundwater hydrochemistry in some parts of Krushanprasad block was determined to assess its quality. Krushnaprasad block is not a single Unit. Some part of it is situated in the main land and some part in form of island within Chilika lagoon. Groundwater samples from 30 different island locations were collected in the post monsoon season. It was found that the groundwater is rich in sodium, magnesium and chloride ions as compared to calcium, potassium, bicarbonate and sulphate ions. The analysis was carried out as per international standards. The groundwater is high in TDS. The parameters chloride / bicarbonate, magnesium/calcium were used to identify the intrusion of salt water in the coastal aquifers. It was concluded that groundwater of Krushnaprasad block in the island regions is in danger under the saltwater intrusion condition. The main groundwater type is sodium chloride type followed by Magnesium chloride waters. The groundwater in most part of the study area is not fit for drinking and for agriculture. The anthropogenic factor may be taken as one of the factors for seawater intrusion. The results were observed and compared with standards of WHO, ICMR and ISI so as to determine its suitability for different use.
\end{abstract}

\section{INTRODUCTION}

In Odisha, many rural settlement pockets are located along the coastal tracts. In these centers, apart from dwelling apartments, industrial organizations have also come up. Due to this demographic setting, overexploitation of groundwater resources are found to be taking place. Except in the Summer, the status of fresh water availability remains satisfactory. Fresh water becomes available from surface sources such as ponds and rivers. During this time, the groundwater is rarely utilized. However in the summer, surface water depletes and groundwater comes under mounting pressure both from human settlements and from industrial units. Due to continuous drawl of 
groundwater, the water level goes down and invites the adjoining saline water to invade the fresh water areas giving rise to salt water intrusion. Such occurrences of saline water has been reported from different pockets of coastal Odisha, such as Balasore, Bhadrak, Jagatsinghpur, Puri and Ganjam. In such situations, the groundwater has to be assessed for its use for drinking, industry and agriculture. Saline water may pollute the fresh water wells. It may lead to rusting of industrial components and use of saline water may bring negative growth to standing crops. Though much work has been carried out in northern coasts, the central part of coastal Odisha lacks such research work. For this purpose, a part of Krushnaprasad block has been selected and was taken for carrying out the groundwater quality work.

\section{STUDY AREA}

The study area (Fig. 1) is located between longitudes $85^{\circ} 10^{\prime} 28.38^{\prime \prime}$ 'E and $85^{\circ} 37^{\prime}$ $50.68^{\prime \prime} \mathrm{E}$ and latitudes $19^{\circ} 28^{\prime} 00.58^{\prime}$ ' $\mathrm{N}$ and $19^{\circ} 53^{\prime} 02.25^{\prime \prime} \mathrm{N}$ falling in Survey of India toposheet no. E45B2, E45B6, and E45B10, in 1:50,000 scale and covers an area of about $151 \mathrm{~km}^{2}$ in Krushnaprasad, in the coastal belt of Odisha. It is located approximately $75.6 \mathrm{~km}$ east of the district headquarter, Puri. Its elevation is $25 \mathrm{~m}$ above sea level and is about $174 \mathrm{~km}$ away from the state capital Bhubaneswar. A major part of Krushnaprasad Block in the Puri district is situated in the mainland. Only some portion of this block is situated within the Chilika lagoon as islands. Even some villages are found in the spits and barriers in the periphery of the lagoon system. National estimation of beach change has identified Krushnaprasad as one of the environmental hotspots and, in eastern coastal tract of Odisha, the salinity hazard is widespread.

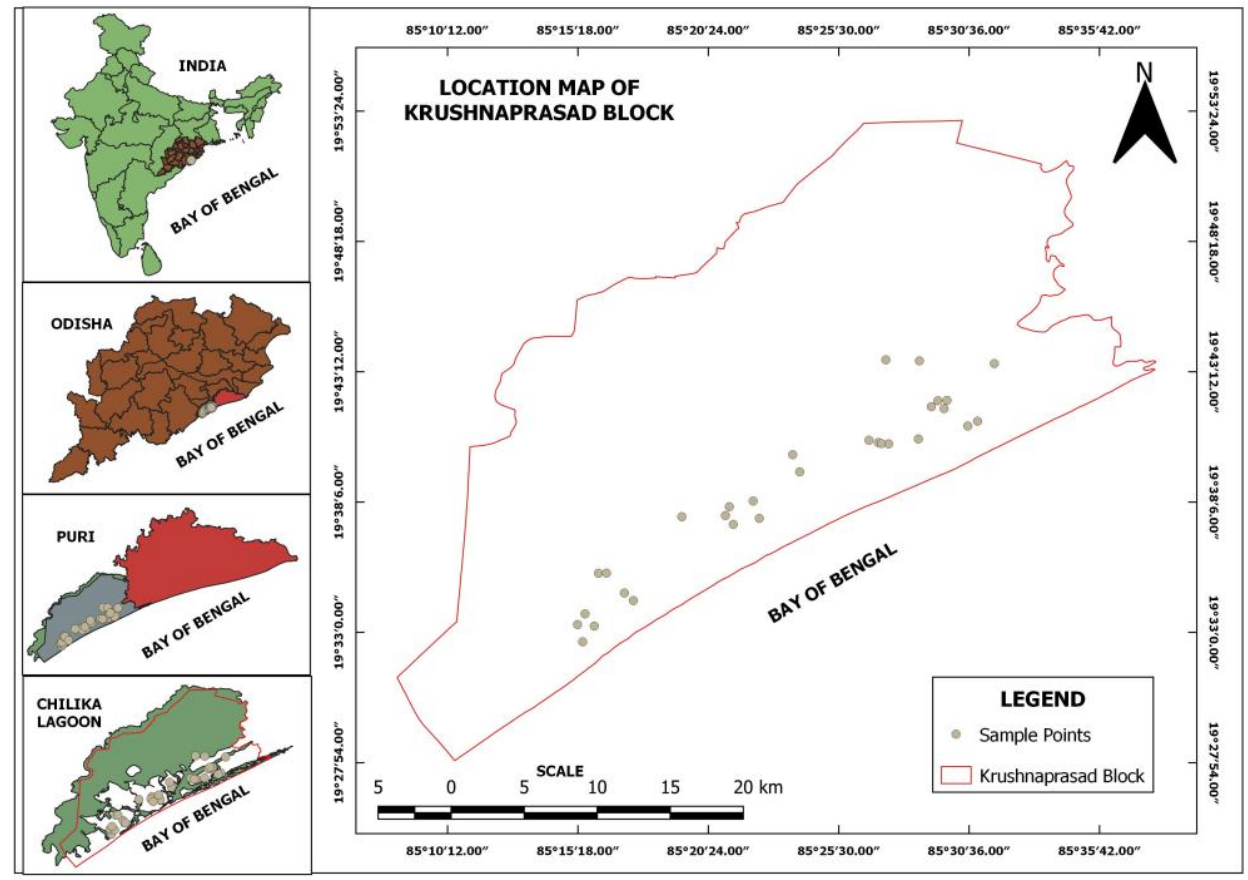

Fig. 1: Location map of Krushnaprasad block 


\section{GEOLOGY AND GEOMORPHOLOGY OF THE STUDY AREA}

The entire Puri district can be subdivided into two natural divisions - (I) the littoral tract and (II) the alluvial tract. The littoral tract which takes the form of a sandy ridge varies approximately $6.5 \mathrm{~km}$ to a few hundred metres in width and lies between the alluvial tract and the Bay of Bengal. There are ridges in this tract which have been formed due to accumulations of windblown sand. The alluvial tract has been formed mainly due to the deposition of the southern branches of the Mahanadi River. The broad soil group of the eastern and south eastern coastal plain of Odisha to which Krushnaprasad belongs is essentially deltaic alluvial and lateritic in nature.

The study area forms part of Mahanadi delta and it is underlain by unconsolidated alluvial sediments of Sub-Recent to Recent periods. According to Mahalik (2000) ${ }^{10}$, the sediments comprise mainly of sand, clay, gravel and silt of varying proportions. The sand and gravel layers generally form potential aquifers. The sediments deposited are in heterogeneous pattern due to several phases of marine transgression and regression and depositional environments.

The Quaternary period consists of laterites and alluvium. While the laterite occurs only in the western and north-western parts, major parts of the area are covered by alluvium of varying thickness. The older alluvium is generally exposed in the northwestern parts including a sequence of sand, clay and kankars of grey to brown in colour. The younger alluvium, which covers nearly $90 \%$ of the area, occurs as floodplain deposits along the course of major rivers and streams. These sediments consist of an admixture of silt, sand, gravel and pebble in varying proportions. These layers increase in thickness towards the sea, showing a gentle dip. Discontinuous ridges of sand dunes occur along the coast and are formed due to wind action.

(i) Areas underlain by alluvium.

(ii) Areas underlain by fractured, fissured and consolidated basement rock formations.

A few ash beds of volcanic origin have been recorded in Mahanadi river valleys. It is believed that they are belonging to an age of 74,000 years. Besides the above, Quaternary sediments are met with in both coastal tracts and upland river valley.

Hydrogeologically, the Puri district can be sub-divided into 3 broad regions viz; unconsolidated formation, consolidated formation and the hilly areas. The unconsolidated formation comprises of sand, silt, clay and $30 \%$ of the district is underlain by this formation. The groundwater in near surface shallow aquifer occurs under pheratic conditions, even down to a depth of $135 \mathrm{~m}$ below ground level.

\section{DATA AND METHODOLOGY}

All the data used for preparing this paper are primary in nature and they are mostly belonging to the hydrochemical domain of groundwater in parts of Krushnaprasad Block. For that purpose, thirty groundwater samples were collected from different sites of Krushanprasad Block in clean, well dried plastic bottles during the pre- 
monsoon period. Water samples were analysed for temperature, $\mathrm{pH}$, Electrical conductivity (EC), Total Dissolved solids (TDS), bicarbonate, total hardness, calcium, magnesium, chloride, sulphate, sodium, and potassium. Electrical conductivity and $\mathrm{pH}$ of the water samples were measured in the field instantaneously with potable Systronics $\mathrm{pH}$ and $\mathrm{EC}$ meters. $\mathrm{Ca}^{++}$and $\mathrm{Mg}^{++}$were determined by titrating with standard EDTA. $\mathrm{Cl}^{-}$was estimated titrimetrically using standard $\mathrm{AgNO}_{3}$ solution. $\mathrm{Na}^{+}$ and $\mathrm{K}^{+}$were determined using a Systronics flame photometer of type 128. $\mathrm{SO}_{4}^{--}$was determined by turbidimetric method (Clesceri et.al.1998) ${ }^{4}$. The collection, preservation and the analysis of various physico-chemical parameters were analysed according to APHA (1985) $)^{3}$ guidelines.

\section{RESULTS}

The results of chemical analysis of the groundwater samples are presented in Table-1 and, Table- 2 shows the range in values along with World Health Organization (WHO, 1993) ${ }^{17}$ standards. The data show that the samples are enriched in $\mathrm{Na}^{+}, \mathrm{Ca}^{++}, \mathrm{Mg}^{++}$, $\mathrm{Cl}^{-}$and $\mathrm{HCO}_{3}{ }^{-}$ions as compared to $\mathrm{K}^{+}$and $\mathrm{SO}_{4}^{--}$ions.

Table 1. Water Quality Parameters and their concentrations (in $\mathrm{mg} / \mathrm{l}$ ), ratio parameters

with no dimension

\begin{tabular}{|c|c|c|c|c|c|c|c|c|c|c|c|c|c|}
\hline LOCATION & $\mathrm{Ca}^{++}$ & $\mathrm{Mg}^{++}$ & $\mathrm{Na}^{+}$ & $\mathrm{K}^{+}$ & $\mathrm{HCO}_{3}^{-}$ & $\mathrm{Cl}^{-}$ & $\mathrm{SO}_{4}^{--}$ & TDS & $\mathrm{Na}^{+} / \mathrm{Cl}^{-}$ & $\mathrm{Cl}^{-} / \mathrm{HCO}_{3}^{-}$ & $\mathrm{Mg}^{++} / \mathrm{Ca}^{++}$ & $\mathrm{TH}$ & $\% \mathrm{Na}$ \\
\hline Fatepur & 34.92 & 30.49 & 854.20 & 374.60 & 754.73 & 1243.00 & 96.20 & 3398 & 1.06 & 2.83 & 1.44 & 300 & 91.66 \\
\hline Adalabad & 65.00 & 35.00 & 873.98 & 29.09 & 743.75 & 1048.92 & 63.81 & 2875 & 1.28 & 2.43 & 0.89 & 320 & 86.36 \\
\hline Ora & 10.00 & 26.49 & 469.80 & 27.41 & 1135.97 & 81.34 & 88.25 & 1852 & 8.91 & 0.12 & 4.37 & 290 & 88.75 \\
\hline Hunda & 30.00 & 43.34 & 808.92 & 35.03 & 2332.61 & 72.74 & 24.40 & 3359 & 17.15 & 0.05 & 2.38 & 280 & 87.70 \\
\hline Balarampur & 75.00 & 27.95 & 135.80 & 38.33 & 322.03 & 175.00 & 20.62 & 820 & 1.20 & 0.94 & 0.61 & 160 & 53.27 \\
\hline Gilinasi & 45.00 & 40.30 & \begin{tabular}{|l|}
1080.77 \\
\end{tabular} & 48.39 & 455.06 & 1581.73 & 75.00 & 3345 & 1.05 & 5.98 & 1.48 & 189 & 89.67 \\
\hline Kanheipur & 57.00 & 35.55 & 742.83 & 52.47 & 209.67 & 1209.35 & 22.10 & 2341 & 0.95 & 9.93 & 1.03 & 360 & 85.37 \\
\hline Patapur & 10.00 & 18.24 & 198.43 & 48.29 & 245.00 & 125.00 & 24.90 & 676 & 2.45 & 0.88 & 3.01 & 320 & 83.15 \\
\hline Harichandanpur & 12.00 & 24.68 & 166.50 & 185.14 & 275.00 & 150.00 & 37.94 & 862 & 1.71 & 0.94 & 3.39 & 270 & 82.00 \\
\hline Biripadar & 16.00 & 41.08 & 1380.72 & 32.52 & 379.01 & 2059.73 & 18.20 & 3938 & 1.03 & 9.35 & 4.23 & 400 & 93.58 \\
\hline Balijagannathpur & 8.00 & 51.62 & 269.50 & 44.03 & 412.22 & 258.21 & 28.50 & 1082 & 1.61 & 1.08 & 10.64 & 650 & 73.45 \\
\hline Deulaparha & 22.00 & 39.18 & 292.02 & 72.90 & \begin{tabular}{|l|}
487.06 \\
\end{tabular} & 242.76 & 150.00 & 1315 & 1.85 & 0.86 & 2.94 & 280 & 77.12 \\
\hline Patharakata & 28.00 & 12.40 & \begin{tabular}{|l|}
1269.74 \\
\end{tabular} & 75.43 & 1066.28 & 1428.72 & 75.00 & 3965 & 1.37 & 2.31 & 0.73 & 190 & 95.94 \\
\hline Chadheya & 32.00 & 43.17 & 184.04 & 112.05 & 241.23 & 204.10 & 55.00 & 885 & 1.39 & 1.46 & 2.22 & 483 & 67.86 \\
\hline Bhabanipur & 100.00 & 78.00 & 588.30 & 37.16 & 830.23 & 735.52 & 25.00 & 2410 & 1.23 & 1.52 & 1.29 & 178 & 69.94 \\
\hline Parala & 29.96 & 31.75 & 1072.45 & 107.56 & 322.00 & 1669.35 & 32.00 & 3277 & 0.99 & 8.92 & 1.75 & 179 & 92.33 \\
\hline Baghamunda & 50.92 & 31.06 & 868.05 & 34.94 & 211.00 & 1398.52 & 38.00 & 2651 & 0.96 & 11.41 & 1.01 & 195 & 88.35 \\
\hline Banamalipurpatna & 85.00 & 26.50 & 422.02 & 65.47 & 160.00 & 617.51 & 30.00 & 1416 & 1.05 & 6.64 & 0.51 & 200 & 75.73 \\
\hline Guptapur & 45.21 & 24.82 & 161.10 & 50.85 & 150.00 & 329.10 & 40.00 & 820 & 0.75 & 3.78 & 0.91 & 320 & 65.91 \\
\hline Nathpur & 31.00 & 47.43 & 292.01 & 51.85 & 358.04 & 243.65 & 42.20 & 1080 & 1.85 & 1.17 & 2.52 & 220 & 72.02 \\
\hline Bankijal & 19.00 & 29.17 & 1269.50 & 40.30 & 156.00 & 1999.81 & 45.20 & 3567 & 0.98 & 22.06 & 2.53 & 240 & 94.38 \\
\hline Baulapatana & 50.00 & 12.24 & 827.37 & 33.89 & 125.99 & 1298.52 & 67.10 & 2431 & 0.98 & 17.74 & 0.40 & 270 & 91.32 \\
\hline Alupatana & 24.96 & 34.88 & 1042.41 & 28.75 & 158.99 & 1665.58 & 25.50 & 2994 & 0.97 & 18.03 & 2.30 & 220 & 91.80 \\
\hline Naubarhi & 42.00 & 32.12 & 388.44 & 43.34 & 190.00 & 566.79 & 82.10 & 1358 & 1.06 & 5.13 & 1.26 & 280 & 79.17 \\
\hline Porhadhihi & 32.00 & 29.18 & 1014.96 & 38.04 & 230.00 & 1528.00 & 110.00 & 2998 & 1.02 & 11.43 & 1.50 & 290 & 91.86 \\
\hline Sana Basantapur & 34.00 & 12.87 & 157.43 & 63.04 & 279.97 & 185.95 & 22.00 & 769 & 1.31 & 1.14 & 0.62 & 320 & 75.43 \\
\hline Gangadharpur & 36.00 & 40.87 & 332.81 & 35.09 & 403.10 & \begin{tabular}{|l|}
450.00 \\
\end{tabular} & 12.00 & 1317 & 1.14 & 1.92 & 1.87 & 225 & 74.88 \\
\hline Mirzapur & 11.00 & 30.35 & 834.24 & 21.29 & 119.18 & \begin{tabular}{|l|}
1334.77 \\
\end{tabular} & 16.00 & 2378 & 0.96 & 19.28 & 4.55 & 410 & 92.36 \\
\hline Gobakund & 26.00 & 20.68 & \begin{tabular}{|l|}
1086.87 \\
\end{tabular} & 33.36 & 561.13 & 1442.02 & 20.00 & 3220 & 1.16 & 4.42 & 1.31 & 290 & 94.14 \\
\hline Bhagabanpur & 24.00 & 18.17 & 1660.19 & 33.40 & 268.22 & 2493.39 & 24.10 & 4539 & 1.03 & 16.00 & 1.25 & 175 & 96.45 \\
\hline
\end{tabular}


Table 2: Water Quality Standards of various agencies:

\begin{tabular}{|c|c|c|c|c|c|}
\hline $\begin{array}{l}\text { Sl. } \\
\text { No. }\end{array}$ & Parameters & $\begin{array}{l}\text { Observed } \\
\text { Range of values } \\
\text { in } \mathrm{mg} / \mathrm{l}\end{array}$ & $\begin{array}{l}\text { ISI } \quad \text { Maximum } \\
\text { Permissible limits }\end{array}$ & $\begin{array}{l}\text { ICMR Maximum } \\
\text { Permissible } \\
\text { limits }\end{array}$ & $\begin{array}{l}\text { WHO } \\
\text { Guidelines }\end{array}$ \\
\hline 1 & Colour & - & 10 & 25 & \\
\hline 2 & Test & - & Agreeable & Unobjectionable & \\
\hline 3 & Odor & - & Unobjectionable & Unobjectionable & \\
\hline 4 & Turbidity & - & $10 \mathrm{NTU}$ & $25 \mathrm{JTU}$ & \\
\hline 5 & $\mathrm{pH}$ & $7.01-7.72$ & $6.5-8.5$ & $6.5-9.2$ & \\
\hline 6 & TDS (in mg/l) & $676-4539$ & 500 & $1500-3000$ & \\
\hline 7 & TH (in mg/l) & $160-650$ & 300 & 600 & \\
\hline 8 & $\mathrm{Ca}$ (in $\mathrm{mg} / \mathrm{l})$ & $8-100$ & 75 & 200 & 200 \\
\hline 9 & $\mathrm{Mg}$ (in $\mathrm{mg} / \mathrm{l}$ ) & $12.24-78.0$ & 30 & & \\
\hline 10 & $\mathrm{Fe}$ (in $\mathrm{mg} / \mathrm{l}$ ) & - & 0.3 & 1.0 & $\begin{array}{l}10 \text { (Total } \\
\text { Iron) }\end{array}$ \\
\hline 11 & $\mathrm{Cu}$ (in mg/l) & - & 0.05 & 1.5 & 1.5 \\
\hline 12 & Mn (in mg/l) & - & 0.1 & 0.5 & 0.5 \\
\hline 13 & $\mathrm{SO}_{4}$ (in mg/l) & $12.0-150.0$ & 150 & 400 & 400 \\
\hline 14 & $\mathrm{Cl}$ (in $\mathrm{mg} / \mathrm{l}$ ) & $72.24-2493.39$ & 250 & 1000 & 250 \\
\hline 15 & $\mathrm{NO}_{3}$ (in $\mathrm{mg} / \mathrm{l}$ ) & - & 45 & 100 & 10 \\
\hline 16 & $\mathrm{~F}($ in $\mathrm{mg} / \mathrm{l})$ & - & $0.6-1.2$ & 1.5 & 1.5 \\
\hline 17 & $\mathrm{Hg}$ (in $\mathrm{mg} / \mathrm{l}$ ) & - & 0.001 & 0.001 & \\
\hline 18 & $\mathrm{Cd}$ (in $\mathrm{mg} / \mathrm{l}$ ) & - & 0.01 & 0.01 & \\
\hline 19 & As (in mg/l) & - & 0.05 & 0.05 & \\
\hline 20 & Cn (in mg/l) & - & 0.05 & 0.05 & \\
\hline 21 & $\mathrm{~Pb}$ (in $\mathrm{mg} / \mathrm{l}$ ) & - & 0.1 & 0.05 & \\
\hline 22 & $\mathrm{Zn}$ (in mg/l) & - & 0.5 & 0.10 & \\
\hline 23 & $\mathrm{Cr}$ (in $\mathrm{mg} / \mathrm{l}$ ) & - & 0.05 & & \\
\hline 24 & $\mathrm{Na}$ (in $\mathrm{mg} / \mathrm{l}$ ) & $135.8-1600.19$ & - & & 200 \\
\hline
\end{tabular}

The concentration of all the major ions ranged between wide limits. Chemical analysis results indicate that the concentration of $\mathrm{Ca}^{++}, \mathrm{Mg}^{++}, \mathrm{Na}^{+}$and $\mathrm{K}^{+}$ions varied from $8 \mathrm{mg} / 1$ to $100 \mathrm{mg} / 1,12.24 \mathrm{mg} / 1$ to $78.0 \mathrm{mg} / 1,135.8 \mathrm{mg} / 1$ to $1600.19 \mathrm{mg} / \mathrm{l}$ and 21.29 $\mathrm{mg} / \mathrm{l}$ to $374.60 \mathrm{mg} / \mathrm{l}$ respectively. On the other hand, the anions such as $\mathrm{Cl}^{-}, \mathrm{HCO}_{3}^{-}$, and $\mathrm{SO}_{4}^{--}$showed variation from $72.74 \mathrm{mg} / 1$ to $2493.39 \mathrm{mg} / 1,119.1824 \mathrm{mg} / 1$ to $2332.61 \mathrm{mg} / \mathrm{l}$, and $12.0 \mathrm{mg} / \mathrm{l}$ to $150.0 \mathrm{mg} / \mathrm{l}$, respectively. The concentration of $\mathrm{Na}^{+}$at Fatepur, Adalabad, Ora, Hunda, Gilinasi, Kanheipur, Biripadar, Balijagannathpur, Deulaparha, Patharakata, Bhabanipur, Parala, Baghamunda, Banamalipurpatna, Nathpur, Bankijal, Baulapatana, Alupatana, Naubarhi, Porhadhihi, Gangadharpur, Mirzapur, Gabakund, Bhagabanpur locations Showed higher values than what is recommended by WHO as Maximum Permissible Limit for drinking water.

Total hardness (TH) indicates the trend in the concentration of $\mathrm{Ca}^{++}$and $\mathrm{Mg}^{++}$with a value ranging from $160 \mathrm{mg} / 1$ to $650 \mathrm{mg} / \mathrm{l}$. The total dissolved solids (TDS) values, representing the total salt content in the water, ranged between $676 \mathrm{mg} / \mathrm{l}$ and 4539 $\mathrm{mg} / \mathrm{l}$, amongst which at locations Fatepur, Adalabad, Ora, Hunda, Gilinasi, 
Kanheipur, Biripadar, Balijagannathpur, Deulaparha, Patharakata, Bhabanipur, Parala, Baghamunda, Banamalipurpatna, Nathpur, Bankijal, Baulapatana, Alupatana, Naubarhi, Porhadhihi, Gangadharpur, Mirzapur, Gabakund, Bhagabanpur, the values were higher than the recommended value of $1000 \mathrm{mg} / \mathrm{l}$, the maximum permissible limit for water.

Drinking water standards are generally based on two main criteria (Davis and De Wiest, 1966) ${ }^{6}$ : (1) presence of objectionable tastes, odor, and color and (2) presence of substances with adverse physiological (health effects) characteristics. The chemical analysis results showed that the groundwater in the landward locations of the study area is potable, but waters close to shrimp ponds are unfit for drinking as they contain objectionable levels of TDS, $\mathrm{Na}^{+}$and $\mathrm{Cl}^{-}$.

\section{DISCUSSION:}

Most of the study area are entirely situated in islands and is geomorphologically situated in the continental shelf of East Coast of India. The geology is dominated by Quaternary sediments which are reworked several times before they rest finally to form the island. These islands have assembled themselves into spits and bars in the eastern periphery of the lagoon. So, it can be deciphered that the sediments are ultimately deposited here which once upon a time were exposed in the mainland. It, therefore, can be concluded that the major ions have been derived from the rock forming minerals constituting the lithology of the terrestrial domain. In normal conditions also, the regional geology determines the hydrochemistry of groundwater (Amadi, 1987) ${ }^{2}$. However, the erratic concentrations of the major ions observed in the water samples can be attributed to cation exchange process involving the aquifer materials (Mercado, 1985) ${ }^{11}$. However, a major trend that has been observed in this work is the elevated level of TDS, chloride, magnesium and sodium ions which are much much higher in content in the central regions of the islands.

The occurrence of salt water mixing or salt water intrusion can well be verified by considering the total dissolved contents (TDS) of the groundwater. The level of TDS in normal groundwater is generally less than $500 \mathrm{mg} / \mathrm{l}$. In inland areas, groundwater at greater depths records higher TDS due to dissolution of mineral matter in groundwater. It is very rare that the TDS crosses $1000 \mathrm{mg} / \mathrm{l}$ mark. However, in coastal locations, groundwater is easy to mix with adjoining sea water to assimilate more salt to it thus increasing the TDS level to a greater level. In the present study, the TDS varied between $676 \mathrm{mg} / 1$ to $4539 \mathrm{mg} / 1$ out of which Fatepur, Adalabad, Ora, Hunda, Gilinasi, Kanheipur, Biripadar, Balijagannathpur, Deulaparha, Patharakata, Bhabanipur, Parala, Baghamunda, Banamalipurpatna, Nathpur, Bankijal, Baulapatana, Alupatana, Naubarhi, Porhadhihi, Gangadharpur, Mirzapur, Gabakund, Bhagabanpur number of samples reported TDS greater than $1000 \mathrm{mg} / 1$ and Fatepur, Adalabad, Ora, Hunda, Gilinasi, Kanheipur, Biripadar, Patharakata, Bhabanipur, Parala, Baghamunda, Bankijal, Baulapatana, Alupatana, Porhadhihi, Mirzapur, Gabakund, Bhagabanpur number of samples reported their TDS even greater than 
$1500 \mathrm{mg} / \mathrm{l}$. This TDS level is sufficient to prove that the groundwater is salt affected. Another important fact is that 18 samples have their TDS greater than $1500 \mathrm{mg} / \mathrm{l}$ and Fatepur, Adalabad, Hunda, Gilinasi, Kanheipur, Biripadar, Patharakata, Bhabanipur, Parala, Baghamunda, Bankijal, Baulapatana, Alupatana, Porhadhihi, Mirzapur, Gabakund, Bhagabanpur samples have their TDS more than even $2000 \mathrm{mg} / \mathrm{l}$. This indicates that the water is not normal, rather they are affected by seawater intrusion.

The phenomenon of seawater intrusion has been elaborately observed by Lusezynski and Swarzenski $(1966)^{9}$ who opined that concentration of chloride greater than 50 $\mathrm{mg} / \mathrm{l}$ indicates saltwater intrusion. Similarly, Trembley et al. $(1973)^{15}$, during their research survey in the summer side area of Prince Edward Island opined that the concentration level of chloride higher than $40 \mathrm{mg} / 1$ indicates saltwater intrusion. Amadi (1989) ${ }^{1}$ during his work in Niger delta found that the chloride concentration greater than $50 \mathrm{mg} / 1$ points towards seawater intrusion. In the present study, the groundwater samples collected from the coastal parts of the island and also in the inland areas have recorded greater level of Chloride. Almost all the samples have their Chloride concentration more than $50 \mathrm{mg} / \mathrm{l}$. The Chloride varied between $72.74 \mathrm{mg} / \mathrm{l}$ to 2493 mg/l out of which Fatepur, Adalabad, Balarampur, Gilinasi, Kanheipur, Patapur, Harichandanpur, Biripadar, Balijagannathpur, Deulaparha, Patharakata, Chadhaeya, Bhabanipur, Parala, Baghamunda, Banamalipurpatna, Guptapur, Nathpur, Bankijal, Baulapatana, Alupatana, Naubarhi, Porhadhihi, Sana Basantpur, Gangadharpur, Mirzapur, Gabakund, and Bhagabanpur number of samples reported Chloride greater than $100 \mathrm{mg} / 1$ and Fatepur, Adalabad, Gilinasi, Kanheipur, Biripadar, Patharakata, Bhabanipur, Parala, Baghamunda, Banamalipurpatna, Bankijal, Baulapatana, Alupatana, Naubarhi, Porhadhihi, Mirzapur, Gabakund, and Bhagabanpur number of samples reported their Chloride greater than $500 \mathrm{mg} / \mathrm{l}$. The Chloride recorded is even greater than $1000 \mathrm{mg} / \mathrm{l}$ at Fatepur, Adalabad, Gilinasi, Biripadar, Patharakata, Parala, Baghamunda, Bankijal, Baulapatana, Alupatana, Porhadhihi, Mirzapur, Gabakund, and Bhagabanpur number of places. Elevated levels of TDS is also an indication of salt water intrusion.

The occurrence of seawater intrusion is also confirmed by higher value $\mathrm{Cl}^{-} / \mathrm{HCO}_{3}{ }^{-}$ and $\mathrm{Mg}^{++} / \mathrm{Ca}^{++}$(Todd, 1976) ${ }^{14}$. The results in Table-1 may be observed. It is seen that many places have recorded their $\mathrm{Cl}^{-} / \mathrm{HCO}_{3}^{-}$greater than 2. Out of 30 locations, around 18 locations have recorded their $\mathrm{Cl}^{-} / \mathrm{HCO}_{3}{ }^{-}$greater than 2. Such places are Fatepur, Adalabad, Gilinasi, Kanheipur, Biripadar, Patharakata, Parala, Baghamunda, Banamalipurpatna, Guptapur, Bankijal, Baulapatana, Alupatana, Naubarhi, Porhadhihi, Mirzapur, Gabakund and Bhagabanpur. The ratio parameter $\mathrm{Mg}^{++} / \mathrm{Ca}^{++}$ may also be considered. Out of 30 locations, around 12 locations have recorded their $\mathrm{Mg}^{++} / \mathrm{Ca}^{++}$greater than 2. These places are Ora, Hunda, Patapur, Harichandanpur, Biripadar, Balijagannathpur, Deulaparha, Chadheya, Natpur, Bankijal, Alupatana, and Mirzapur. The study of both the above two ratio parameters indicate that salt water intrusion has taken place due to which the groundwater shows higher levels of various ions. Similar works have been carried out by Dalai et al. $(2019)^{5}$ in Ersama coast and by Panda et al. (2020) ${ }^{12}$ in Kendrapada coast wherein they adopted the TDS and ratio 
parameter methods to identify and delineate sea water intrusion into fresh water aquifers.

The wide range of variations of ionic contents have given rise to several groundwater types. To get the exact picture of the groundwater chemistry and major groundwater types, the results were plotted in Piper's Diagram and Extended Durov's Diagram. These diagrams are shown in Fig-2 and Fig-3. In both the diagram, the concentration of $\mathrm{Na}$ and $\mathrm{Mg}$ is visibly much higher as compared to $\mathrm{Ca}$ and $\mathrm{K}$. On the other hand, from among the anions, the chloride dominated the fields as compared to Carbonate and Sulpahte. As the $\mathrm{Na}$ and Chloride ions dominate in the coastal locations, the groundwater types in the peripheral areas are of $\mathrm{Na}-\mathrm{Cl}$ type. This water type is prevalent at Fatepur, Adalabad, Balarampur, Gilinasi, Kanheipur, Patapur, Harichandanpur, Biripadar, Patharakata, Chadhaeya, Bhabanipur, Parala, Baghamunda, Banamalipurpatna, Guptapur, Bankijal, Baulapatana, Alupatana, Naubarhi, Porhadhihi, Sana Basantpur, Gangadharpur, Mirzapur, Gabakund, and Bhagabanpur. The second water type is $\mathrm{Mg}-\mathrm{Cl}$ type, as evident from Fig-2 and Fig-3. Since the second dominant cation is $\mathrm{Mg}$, the $\mathrm{Mg}-\mathrm{Cl}$ type occurs adjacent to the $\mathrm{Na}-\mathrm{Cl}$ type. This type of water is seen at Ora, Hunda, Patapur, Harichandanpur, Balijagannathpur, Deulaparha, and Nathpur, The bicarbonates are very less. So no carbonate type of groundwater is prevalent. Since only two or three points are plotted in $\mathrm{Ca}-\mathrm{CO}_{3}$ area, this type of water type is very rare. It may be possible only at the middle of the study area where rain water is the only source of groundwater without being mixed with salt water.

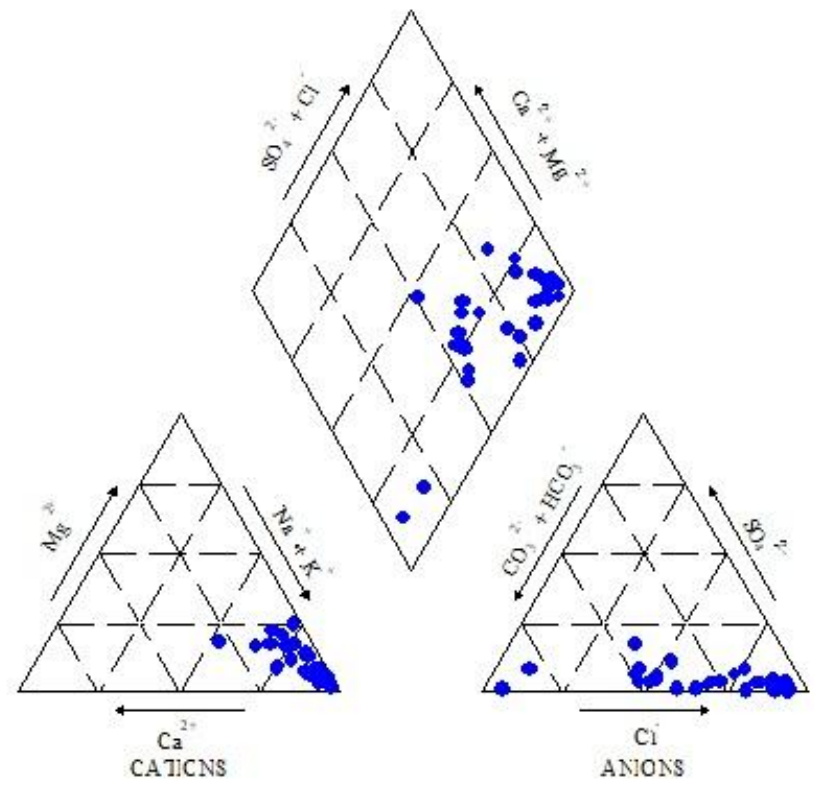

Fig. 2 Piper's Diagram 


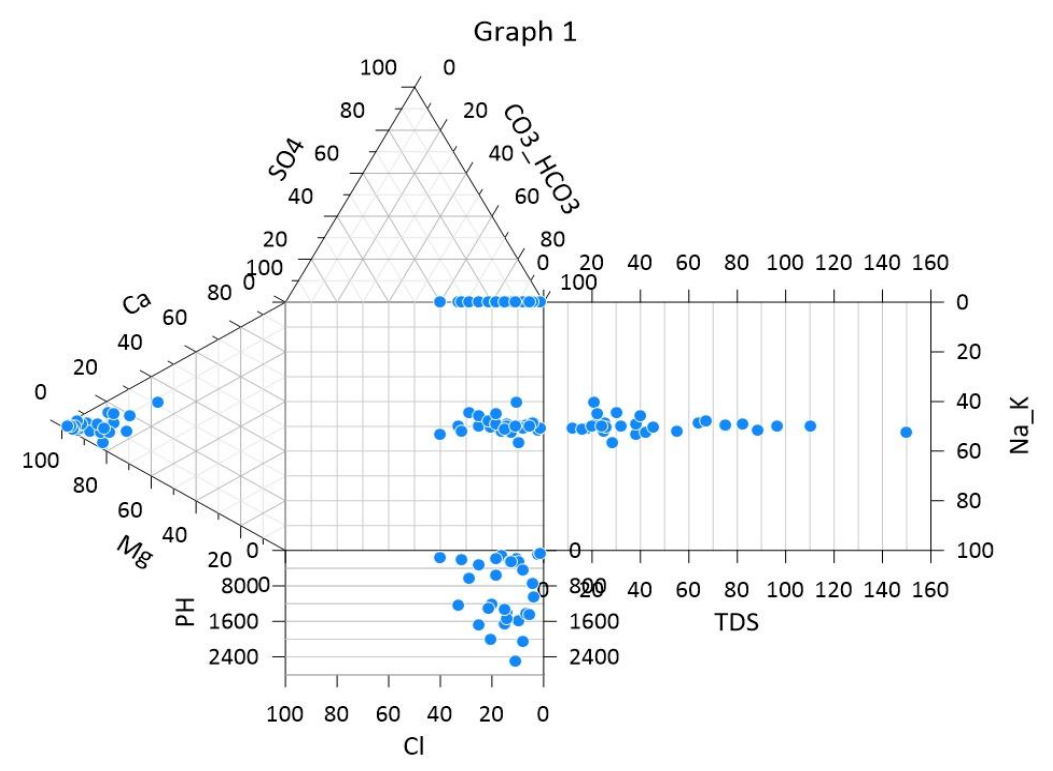

Fig. 3 Durov's diagram

The evolution of groundwater types can, to a satisfactory extent, be explained with the help of the "theory of encounter" proposed by Freeze and Cherry (1979) ${ }^{8}$. The theory states that the order in which groundwater encounters strata of different mineralogical composition can exert important control on the final water chemistry. As groundwater moves through varying mineralogical strata, the water composition undergoes adjustment of various ionic species, caused by imposition of new mineralogically controlled thermodynamic constraints.

Evolution of groundwater from alkaline earth carbonate type to sodium chloride type was discussed in detail by Tijani (1994) ${ }^{13}$. The author observed that in a basement complex terrain, alkaline earth carbonate type water occurs in the primary stage of evolution, whereas sodium chloride type occurs in the final stage. The geological literature shows that a major part of the study area covers sediments brought out from the Eastern Ghats, which form the basement complex of the study area, and the occurrence of calcium bicarbonate water type conforms with the observation made by Tijani (1994) $)^{13}$. Generally, within the evolutionary trend, groundwater tends to acquire a chemical composition similar to that of sea water (i.e. more dissolved solids and a relative increase in chloride ion) the longer it remains underground and the further it travels (Driscoll, 1986) ${ }^{7}$. Following the above logic, in this study, the alkaline earth carbonates, while flowing through the Quaternary sediments, finally emerge as $\mathrm{NaCl}$ type water, with magnesium chloride waters occurring as final water type. However, absence of Calcium carbonate type of water may be due to continuous interactions of primary water with sea water has converted the fresh waters into sodium chloride water types, with the cation exchange process playing the leading role. Though the evolution process appears to be complete, absence of intermediate type of water types, such as magnesium carbonate and sodium carbonate indicates 
that the cation exchange process was vigorous so that the entire fresh water has been converted into the end water type-i.e. sodium chloride type.

\section{Suitability of groundwater for drinking purpose:}

It has been observed that at most have location the TDS is greater than $1000 \mathrm{mg} / \mathrm{l}$ with which this maximum permissible limit of salinity set by WHO. Similarly, the concentration of $\mathrm{Na}^{+}$is also appreciable to the extent that they have crossed limit of $50 \mathrm{mg} / \mathrm{l}$ which is the limit set by WHO. The concentration of $\mathrm{Cl}^{-}$is also of importance since it, along with $\mathrm{Na}^{+}$and TDS, has greater health implications. Analysis results show that, the concentration of $\mathrm{Cl}^{-}$at many locations has recorded more than the maximum permissible limit of $50 \mathrm{mg} / \mathrm{l}$. In combination, the locations which show higher concentration of TDS, $\mathrm{Na}^{+}$and $\mathrm{Cl}^{-}$are locations Fatepur, Adalabad, Gilinasi, Kanheipur, Biripadar, Balijagannathpur, Deulaparha, Patharakata, Bhabanipur, Parala, Baghamunda, Banamalipurpatna, Nathpur, Bankijal, Baulapatana, Alupatana, Naubarhi, Porhadhihi, Gangadharpur, Mirzapur, Gabakund, and Bhagabanpur. Groundwater of these places are not at all potable. Only very few places have recorded their TDS less than $1000 \mathrm{mg} / \mathrm{l}$. They are Balarampur, patapur, Harichandanpur, Chadhiya, Guptapur, and Sanabasantapur. Groundwater at these locations is safe to drink.

\section{Suitability for agriculture use:}

In addition to drinking water, the groundwater is also used for irrigation in the coastal areas. Since the study area is an island, the effect of seawater on groundwater in changing its hydrochemistry is important from the point of view of irrigation. For irrigation, it is very much important to observe the concentration of sodium $\left(\mathrm{Na}^{+}\right)$in the groundwater because it acts as a soil conditioner and determines the capacity of the plant roots to suck water from the ground for its ultimate use by the plant. Basing on $\mathrm{Na} \%$, Wilcox $(1955)^{16}$ classified the groundwater into five categories such as excellent, good, permissible, doubtful and unsuitable. The $\% \mathrm{Na}$ is calculated by the formula

$$
\% \mathrm{Na}=\frac{\mathrm{Na}+\mathrm{K}}{\mathrm{Ca}+\mathrm{Mg}+\mathrm{Na}+\mathrm{K}} \times 100
$$

Here the ions are expressed in meq/l. The $\% \mathrm{Na}$ of the groundwater are presented in Table-1. Observation of the figures in the table indicate that the groundwater is excellent at location nos. NIL having $\% \mathrm{Na}<20$. The groundwater categorized as 'Good' are seen at no location which are having $\% \mathrm{Na} 20-40$. The groundwater is permissible at location - Balarampur, which are having $\% \mathrm{Na} 40-60$. The groundwater is categorized as 'Doubtful' (\%Na 60-80) at locations- Balijagannathpur, Deulaparha, Chadhiya, Bhabanipur, Banamalipurpatna, Guptapur, Nathpur, , Naubarhi, Sanabasantapur, and Gangadharpur. However, at most of the locations the groundwater is 'Unsuitable' because they are having $\% \mathrm{Na}>80$. These locations are 
Fatepur, Adalabad, Ora, Hunda, Gilinasi, Kanheipur, Patapur, Harichandanpur, Biripadar, Patharakata, Parala, Baghamunda, Bankijal, Baulapatana, Alupatana, Porhadhihi, Mirzapur, Gabakund, and Bhagabanpur.

\section{CONCLUSION:}

Groundwater samples collected from 30 village locations showed wide range of variations in TDS and they are found to be enriched in $\mathrm{Na}^{+}, \mathrm{Mg}^{++}$and $\mathrm{Cl}^{-}$ions as compared to $\mathrm{Ca}^{++}, \mathrm{K}^{+}$and $\mathrm{SO}_{4}^{--}$ions. The mainlands are generally enriched in $\mathrm{Ca}^{++}$ and $\mathrm{HCO}_{3}{ }^{-}$whereas the coastal locations are enriched in $\mathrm{Cl}^{-}$and $\mathrm{Mg}^{++}$ions. These phenomena coupled with occurrence of higher TDS (more than $1000 \mathrm{mg} / \mathrm{l}$ ) clearly shows that saltwater intrusion phenomena is the main cause. The effect of saltwater intrusion is supported by the fact that $\mathrm{Cl}^{-} / \mathrm{HCO}_{3}{ }^{-}$values are higher than 2 at many locations. The groundwater at location Fatepur, Adalabad, Gilinasi, Kanheipur, Biripadar, Patharakata, Parala, Baghamunda, Banamalipurpatna, Guptapur, Bankijal, Baulapatana, Alupatana, Naubarhi, Porhadhihi, ,Mirzapur, Gabakund, Bhagabanpur, have their TDS higher than $1000 \mathrm{mg} / 1$. On the other hand, $\mathrm{Na}^{+}$values higher than $200 \mathrm{mg} / 1$ is prevalent at locationsat Fatepur, Adalabad, Ora, Hunda, Gilinasi, Kanheipur, Biripadar, Balijagannathpur, Deulaparha, Patharakata, Bhabanipur, Parala, Baghamunda, Banamalipurpatna, Nathpur, Bankijal, Baulapatana, Alupatana, Naubarhi, Porhadhihi, Gangadharpur, Mirzapur, Gabakund, and Bhagabanpur. Similarly higher values of $\mathrm{Cl}^{-}$(more than $200 \mathrm{mg} / 1$ ) are repeated at locations Fatepur, Adalabad, Gilinasi, Kanheipur, Biripadar, Balijagannathpur, Deulaparha, Patharakata, Chadhiya, Bhabanipur, Parala, Baghamunda, Banamalipurpatna, Guptapur, Nathpur, Bankijal, Baulapatana, Alupatana, Naubarhi, Porhadhihi, Gangadharpur, Mirzapur, Gabakund, and Bhagabanpur. The groundwater hydrochemistry doesn't allow the population to consume water at these location simply due to the fact that the concentration of $\mathrm{Na}^{+}$, TDS and $\mathrm{Cl}^{-}$are higher than the WHO limits. Though the local geology controls the chemistry of groundwater, higher levels of $\mathrm{Na}^{+}, \mathrm{Mg}^{++}$, TDS and $\mathrm{Na}^{+}$may be contributed by seawater which is all around. The concentration level of $\mathrm{Na}$ was also elaborately discussed so as to determine its suitability for irrigation. Since $\% \mathrm{Na}$ plays a deteriorating role for irrigation, it has been determined accurately. It has been observed that most of the groundwater come under "Unsuitable" and "Doubtful" category. Only a very few locations are reported to be suitable for irrigation. It should therefore be concluded that saltwater intrusion is the main cause for leading the aquifer to be unsuitable for drinking and irrigation purpose.

\section{REFERENCES}

[1] Amadi, P.A.; C.O. Ofoegbu and T. Morrison; (1989). Hydrochemical assessment of groundwater quality in parts of Niger Delta, Nigeria. Environ. Geol. Water Sci., vol. 14, no.3, pp. 195-202. 
[2] Amadi, U.M.P.; (1987). Mixing phenomenon in groundwater systems and its relevance in water quality assessment in Nigeria. Iwugo K (Ed), Paper presented at 2nd annual Symposium/Conference of the Nigerian Water and Sanitation Association, pp 17.1-17.31.

[3] APHA; (1985). Standard methods for examination of water and wastewater. 16th Ed. Washington, D.C.

[4] Clesceri, L. S., Greenberg, A. E., \& Eaton, A. D. (1998). Standard Methods for the Examination of Water and Wastewater APHA. AWWA, WEF,

Monrovia, USA.

[5] Dalai, P.C., Tripathy, J.K., Barik, K.K. and Panda, S.R. (2019). Groundwater hydrochemistry around the shrimp ponds of Ersama and Balikuda blocks of Jagatsinghpur district, Odisha. Pollution Research. Vol.38, pp. S47-S53.

[6] Davis, S.N. and R.J.H. DeWiest; (1966). Hydrogeology. New York, John Wiley \& Sons.

[7] Driscoll, F.G., 1986, Groundwater and Wells, 2nd Edition, St. Paul, Minnesota. Vol. 59, pp. 87-90.

[8] Freez, R.A., and J.A. Cherry, 1979. Groundwater, Englewood Cliffs, New Jersey, Prentice-Hall Inc.

[9] Lusczynski, N.J. and W.V. Swarzenski; (1966). Saltwater intrusion in Southern Nassau and South Eastern Queens Countries. Long Island, New York, U.S. Geological Survey Water Supply Paper 1613F.

[10] Mahalik, N. K. (2000). Mahanadi Delta: geology, resources \& biodiversity. AIT Alumni Association, India Chapter.

[11] Mercado, A.C.; (1985). The use of hydrochemical patterns in carbonate, sand and sandstone aquifers to identify intrusion and flushing of saline water. Groundwater, vol. 23, pp. 635-645.

[12] Panda, S.R., Tripathy, J.K., Dalai, P.C. and Sahoo, S. (2020). Hydrochemical assessment of groundwater in the coastal tract of Kendrapada district, Odisha, India. Adalya Journal. Vol. 9(4), pp. 660-671.

[13] Tijani, M.N., 1994. Hydrochemical assessment of groundwater in Moro area, Kwara state, Nigeria, Environmental Geology, Vol. 24, pp. 194-202.

[14] Todd, D.K., 1976. Monitoring groundwater quality; monitoring methodology, Rept. EPA 600/4-76-026, U.S. Environmental Protection Agency. Las Vegas, pp154.

[15] Trembley, J.J., J. Dtruz and H. Anger; (1973). Saltwater intrusion in the Summerside area, P.E.I. Groundwater, Vol. 11, p. 4.

[16] Wilcox, L.V., 1955. Classification and use of irrigation water, U.S. Dept. Agric. Circ. 969 Washington, D.C., 19 pp.

[17] World Health Organization; (1993). Guidelines for drinking water quality recommendations, Geneva. 